\title{
WORK LIFE BALANCE AND ITS EFFECTS ON ORGANIZATIONAL COMMITMENT: AN EMPIRICAL STUDY AMONG THE NEW MIDDLE CLASS IN KOLKATA, WEST BENGAL
}

\author{
Kahini Palit \\ Assistant Professor, Department of Sociology, School of Liberal Arts and Culture Studies, Adamas \\ University, Kolkata 700126, West Bengal, India \& PhD Research Scholar, Burdwan University
}

Article DOI: https://doi.org/10.36713/epra8351

DOI No: 10.36713/epra8351

\begin{abstract}
Work life balance has become a noteworthy issue having implications both for the organization as well as the employees. The present research inquired into the experiences of the individuals experiencing issues of work life balance, its effects on the life of the individuals and whether it has any relation with their commitments towards their organizations. The methodology for the research was ethnography. 50 respondents, having equal number of working men and women aged between 25-30 years participated in the study. In order to understand the issues in depth, the researcher engaged in long discussions with the respondents to get the insider's perspective of the issue. The findings indicated that work life imbalance was extremely stressful for the employees, and led to reduced output and less organizational commitment from the employees. It also encouraged the employees to quit the job, or look for other opportunities. Work life imbalance for the employees also proved to be detrimental for the organization, who lose committed employees or have employees suffering from fatigue due to stress arising from work life conflict.
\end{abstract}

KEYWORDS: work life balance, organizational commitment, organizational behaviour, human resource management, stress

\section{INTRODUCTION}

The new middle class which emerged in India in the post liberalization period has benefitted from the new economy and the increasing number of job opportunities and variations in career options that the post 1990s development brought along. This was accompanied by the shrinking public sector jobs and increasing private sector jobs. But these new jobs rarely proved to be a panacea against unemployment, and often brought with it new kinds of job-related problems- one among which is work life imbalance. Work life balance indicates an equilibrium between life and work satisfying to the employee (Bataineh, 2019). These jobs in the international banking sector, multinational corporations, the IT sector, to name a few, introduced new job ethos, paid handsome salary, and introduced employees into a corporate lifestyle. The new new middle class was exposed as well as influenced by this change the most, who trained themselves for the particular job skills to be able to qualify for the jobs. Disruption in work life balance often occur in these jobs, because of the increased competitiveness of a globalized market. The responsibilities and job demands often become overwhelming so that it starts to hamper the family responsibilities and the time for rejuvenation. These jobs have been found to be excessively demanding, often much beyond job hours, with expectations exceeding the normal working capability of an employee. The office policies pushed the employee to put in more hours of work, compromising the family commitments and personal time. The blurred line between work and life created conflicts in personal lives (Robbins and Judge 2013). Refuting the perspectives of researchers who advocated that development of technology leads to lessening of conflict between work and life (Waller and Ragsdell, 2012; Hayman 2009; Wheatly, 2012), Robbins and 


\section{EPRA International Journal of Research and Development (IJRD)}

Judge (2013) argued that the development of these very technologies led to more blurring of the line between work and life as the time and place constraint could be eliminated by working from anywhere, anytime.

Typical jobs prior to liberalization had characteristics vastly different from the new and improved jobs in the $21^{\text {st }}$ century. Presently, maintaining work life balance had become extremely challenging, and led to problems of health and stress in the employees. This had vast long-term consequences for the society, and had a direct effect on the employee's workplace. The strain from the work pressure affected, in addition to the personal health of the employee, the family and personal life too. In such a scenario, frustration and depression were often the inevitable outcomes, along with much reduced organizational commitment on the part of the employee. Such employees had also been found to look for other job opportunities elsewhere, and become psychologically ready to quit the job at a moment's notice. Research has shown that catering to the needs of the employees, organizations must develop management of human resources and strategies to maintain work life balance if it wants to stay ahead in the competitive market (Cieri et al, 2005). Greenhaus, Collins and Shaw (2003) observed that employees search for jobs where work life balance could be maintained to improve the quality of life. In order for the organization to manage the human resources effectively and retain efficient employees, providing work life balance has been found to be crucial. Research has found that strengthening the human resources by enhancing positive attitudes lead to better job performance of the employees (Meijerink, Bos-Nehles and Leede, 2018). Supportive attitude on the part of the organization leads to increased commitment of the employees towards the organization and workers show organizational citizenship behaviour (Tsai and Lin, 2014). Similar findings were reported (Pradhan, Jena and Kumara, 2016; Beham 2011 and Lambert, 2000) that when organizations reduced the work life conflict, it enhanced the organizational citizenship behaviour of the workers. Strategies like flexibility of working hours, child care services have been found to reduce work life conflict (McCarthy et al, 2013). According to the research by Thevanes and Mangaleswaran (2018), employees, much above salary and benefits, look towards work life balance before accepting a job. According to Wheatly (2012), providing work life balance is advantageous to both the organization and its employees. Maintaining work life balance by the organizations have better and positive outcomes like productivity, job satisfaction and commitment towards the organization, among many other (Parakandi and behery, 2016; Konrad and Mangel 2000; Lambert 2000). Negligence of issues of work life balance by the organizations lead to lower job performance and productivity. According to Robbins and Judge (2013), organizations neglecting the issue of work life balance of employees would not be able to attract and retain capable employees. Although some researches have been carried out on work-life balance and organizational behaviour, very few have focussed on the qualitative aspects of the employee experiences of work life imbalance. The present research aims to address this research gap, and focusses on understanding the effects of work life imbalance from the perspective of the employees, how they cope with it, and how it affects their loyalty towards their organization.

\section{METHODOLOGY}

The methodology for the present research was Ethnography. Ethnography brought to the fore the qualitative aspects of the experience of work life imbalance on the respondents. The in-depth and sensitive nature of the research required long discussions with the respondents, to listen to their perspectives and problems, their ways of coping with the situations regarding work and life, and their views about their organizations. Understanding organizational commitment of the respondents was also a sensitive area which required the respondents to develop trust towards the researcher. Although quantitative methodology has been used by many previous researchers in this area, the present researcher felt that statistical findings are inadequate to explain the qualitative aspects of the issue in question. For the nature of the enquiry in the present research, the researcher deemed Ethnography as the most appropriate methodology.

\section{Data Collection}

Telephonic interviews as well as face to face interviews were administered to 50 respondents between the age group 25-30 years. Respondents were selected on the basis of Purposive Sampling. The sample was equally divided into male and female respondents in order to avoid gender bias, and subsequently any bias in the results. The study was conducted in North as well as South Kolkata in West Bengal, India, particularly the newly developed neighbourhoods and gated communities like housing complexes, in order to find representative sample among the new middle class. The respondents were employed in private sector jobs- in Multinational Corporations, Private sector Banks, Private Schools and Colleges. All of the jobs were well paid, and consisted of a certain work pressure related to their job roles. Considerable time was spent with each respondent in order to give the respondents the ease 


\section{SJIF Impact Factor 2021: 8.013| ISI I.F.Value:1.241| Journal DOI: 10.36713/epra2016 \\ EPRA International Journal of Research and Development (IJRD)}

Volume: 6 | Issue: 9 | September 2021

- Peer Reviewed Journal

to express themselves. Detailed narratives of the respondents were also recorded to document the respondents' perspectives on the issue in question.

\section{RESULTS AND DISCUSSION}

The findings of the research indicated that owing to the increasing work pressure due to competitive market, work life balance is being disrupted among many in the recent years. There is increasing demand by the employers regarding deadlines and documentations, for which, working overtime without any extra pay has become commonplace. The employers or superiors do not force people to work overtime, but the invisible pressure of the deadlines make them work after hours voluntarily. IT professionals suffer from the work life imbalance almost all the year round. Since working in a laptop does not require one to be in office, they often end up working till late at night with their family asleep in the next room. Respondents expressed the pain of not being able to spend time with their kids or spouses because of abnormal load of office work. Over time, this has created distance between the spouses in many families. But the work pressure remaining constant, it becomes difficult to mend the distance by spending more time. In many instances, even after being entitled to several types of leave, the respondents were rarely at liberty to avail them because of office workload. A number of respondents expressed that the high salary paid by the office becomes secondary if the work pressure mounts beyond tolerable limit. The results of the research did not indicate different results for men and women regarding work life imbalance. Respondents of both sexes expressed disgust and stress regarding work life imbalance, although subjective experiences of men and women differed regarding the issue. For married women, it often led to pressurization by the family to quit the job, from the moment they are not able to attend to the needs of the family. Society, in general, demands the 'homemaker' role of women, and if she is unable to fulfil it on the home front, irrespective of the post and salary, there is a generalized demand to prioritize family. Work life imbalance was also felt severely by working mothers, whose additional responsibility of childcare made their life 'almost a living hell' if severe work pressure encroached on family time. For married men, work life imbalance created distance with their family, and as they compromised family responsibilities for work, they felt judged, and this pressure on both fronts created considerable mental distress which affected their daily life activities.

A major finding in the present research is that work life imbalance and mounting work pressure encouraged less organizational commitment-so that the employees constantly searched for other jobs.
Competent employees who felt confident regarding their work has a much lesser threshold for the endurance of work life conflict, and strived for better opportunity whenever the pressure felt like too much. Such a mentality worked further as an obstacle to endure work pressure.

\section{Working from home and work life balance}

Due to countrywide lockdown due to Covid 19 pandemic, majority offices shifted to 'work from home' for the employees. Respondents expressed that although initially the decision was welcomed with enthusiasm, soon it was revealed that working from home completely destroyed the already waning work life balance. The demands from the employers increased, calling for meetings late in the evenings and weekends became common, and the respondents expressed utter helplessness regarding the authority's negligent attitude to restore the balance. Many felt disappointed with their jobs, and disgusted with the authority who, they felt, wanted to work them like robots in order to increase productivity. But quitting the job was on the mind of many, those who felt that it is affecting their family relationships and health. One such respondents was a mother of a 4 year old child, who remained busy taking online classes the entire day, barely able to attend to the child. Although she had been working in the organization for the past three years, she was seriously thinking about quitting soon, as she felt it is time to give sometime to herself and her family. An interesting thing noted by the researcher here was that salary was not motivation enough for the employees if they felt that their work life balance was destroyed at the cost of it. Many of the respondents expressed that their commitment towards their workplace has been reduced since they were made to feel restless with huge work pressure, and the lack of care on the part of the organization furthered the feeling.

The imbalance between work and life raised a lot of problems. A number of problems could be identified in the study resulting from the dizzy line between work and life. Spending quality time with the family, attending to the family needs, relaxations, attending social gatherings were often skipped for work. The rising stress due to meeting 'targets', or staying ahead in the office competition so as to keep the job, or to be chosen for a promotion prompts more engagement and input in work. The employers are only interested in increased output, so that such competitive environments are created and maintained in the offices. But the waning family ties or lack of necessary relaxations decreased the output of the employees as they felt reluctant to put in quality endeavour. Ignorance of the issue on the part of the employers intensified the problem, as the employees are left to deal with the problem on their own. In 


\section{EPRA International Journal of Research and Development (IJRD)}

certain instances, the offices arranged Motivation workshops to encourage the employees, or Yoga workshops to teach them relaxation and meditation. The respondents whose offices arranged for such workshops, felt that it was an eyewash by the employers, who, instead of reducing office workload tried to teach them ways to relax. Respondents strongly felt that excessive workload cannot be compensated by incentives or yoga workshops, the only way to solve work life imbalance was to reduce the workload and level of expectations from the employees, and provide the necessary means to naturally reduce the imbalance.

\section{CONCLUSION}

The problem of work life balance has gained major attention in the recent years. Research is being conducted in order to understand how to keep employees happy, dedicated towards the organization as well as increase their productivity. In this respect, work life balance issues are the major areas the organizations need to focus on. The findings of this study have corroborated previous findings that imbalance between life and work not only has implications for the individual but the family of the employee too. It has often led to strained relationship in the families who feel neglected, and the feeling of guilt and failure on the part of the individual who unsuccessfully tries to manage both worlds. When such work life balance problems are faced by a considerable number of citizens, it almost rises to the level of a social problem. Moreover, it is absolutely detrimental to the organization itself, who lose valuable employees who quit the job unable to handle the pressure, and the feeling of fatigue generated in the employees due to overworking makes their productivity low. Organizations would be benefitted to devise sustainable work life balance policies which would encourage the employees to contribute productively in the organization and would induce loyalty and dedication towards their workplace. The present study revealed several problem areas generated by lack of balance between work and life, and the individual experiences regarding it. The findings point towards the gravity of the problem, and throws light towards the organizational responsibilities of prioritizing work life balance for its employees, instead of leaving the employees to deal with their own issues. The organizations would not be able to prosper isolated from society, thus taking responsibility of the well-being of the employees are important duties for the organizations. Having a narrow focus on productivity, alienated from the recognition of the employee as a person, would be too near-sighted for the employers, who, as the study confirms, would vastly benefit from happy and relaxed employees who do not stress from work life imbalance.

\section{Conflict of Interests}

The author declares that no competing interests exist.

\section{REFERENCES}

1. Bataineh, K. adnan. (2019). Impact of Work-Life Balance, Happiness at Work, on Employee Performance. International Business Research, 12(2). https://doi.org/10.5539/ibr.v12n2p99

2. Beham, B. (2011). Work-family conflict and organisational citizenship behaviour: empirical evidence from Spanish employees. Community, Work \& Family, 14(1), 63-80. DOI: 10.1080/13668803.2010.506034.

3. Cieri, H., Holmes, B., Abbott, J., \& Pettit, T. (2005). Achievements and challenges for work/life balance strategies in Australian organizations. The International Journal of Human Resource Management, 16(1), 90-103. DOI: 10.1080/0958519042000295966.

4. Galinsky, E., Bond, J. T., \& Hill, E. J. (2004).When work works: A status report on workplace flexibility. New York: Families and Work Institute.

5. Greenhaus, J. H., Collins, K. M., \& Shaw, J. D. (2003).The relation between work-family balance and quality of life. Journal of vocational behavior, 63(3), 510-531.Doi:10.1016/S00018791(02)00042-8.

6. Hayman, J. R. (2009). Flexible work arrangements: Exploring the linkages between perceived usability of flexible work schedules and work/life balance. Community, work \& family, 12(3), $327-$ 338.DOI:10.1080/13668800902966331.

7. Konrad, A. M., \&Mangel, R. (2000). The impact of work-life programs on firm productivity. Strategic management journal, 21(12), 12251237.

8. Lambert, S. J. (2000). Added benefits: The link between work-life benefits and organizational citizenship behavior. Academy of management Journal, 43(5), 801-815.

9. Lambert, E. G., Kelley, T., \& Hogan, N. L. (2013). Work-family conflict and organizational citizenship behaviors. Journal of Crime and $\begin{array}{llll}\text { Justice, } & 36(3), & 398-417 . & \text { DOI: }\end{array}$ 10.1080/0735648X.2012.706402.

10. McCarthy, A., Cleveland, J. N., Hunter, S., Darcy, C., \& Grady, G. (2013). Employee worklife balance outcomes in Ireland: a multilevel investigation of supervisory support and perceived organizational support. The International Journal of Human Resource Management, 24(6), 1257-1276. DOI: 10.1080/09585192.2012.709189.

11. McNall, L. A., Masuda, A. D., \&Nicklin, J. M. (2009). Flexible work arrangements, job satisfaction, and turnover intentions: The mediating role of work-to-family enrichment. The 
Journal of psychology, 144(1), 61-81.DOI: 10.1080/00223980903356073.

12. Meijerink, J., Bos-Nehles, A., \& de Leede, J. (2018). How employees' pro-activity translates high-commitment HRM systems into work engagement: the mediating role of job crafting. The International Journal of Human Resource Management, 1-26. DOI: 10.1080/09585192.2018.1475402.

13. Parakandi, M., \&Behery, M. (2016). Sustainable human resources: Examining the status of organizational work-life balance practices in the United Arab Emirates. Renewable and Sustainable Energy Reviews, 55, 1370-1379. doi:10.1016/j.rser.2015.07.095.

14. Pradhan, R. K., Jena, L. K., \&Kumari, I. G. (2016). Effect of work-life balance on organizational citizenship behaviour: Role of organizational commitment. Global Business Review, 17(3_suppl), 15S-29S. . DOI: 10.1177/0972150916631071.

15. Robbins, S. P., \& Judge, T. A. (2013). Fundamentals of organizational behaviour.15th edition, Pearson Education Canada.

16. Thevanes, N.,\&Mangaleswaran, T. (2018), Relationship between Work-Life Balance and Job Performance of Employees.IOSR Journal of Business and Management, 20(5.), 11-16, DOI: 10.9790/487X-2005011116.

17. Tsui-Hsu Tsai, T., \& Jing Lin, A. (2014). Do psychological contract and organizational citizenship behavior affect organizational performance in non-profit organizations?. Chinese Management Studies, 8(3), 397417.https://doi.org/10.1108/CMS-05-2013-0090.

18. Waller, A. D., \&Ragsdell, G. (2012).The impact of e-mail on work-life balance.Aslib Proceedings, 64(2), $\quad 154 \quad-177$. http://dx.doi.org/10.1108/00012531211215178.

19. Wheatley., D. (2012). Good to be home? Time use and satisfaction levels among home-based teleworkers. New Technology, Work \& Employment, 27(3), 224-241. 